\title{
Land-use planning following resource extraction - Lessons from grizzly bears at reclaimed and active open-pit mines
}

\author{
B. Cristescu Department of Biological Sciences, University of Alberta, Canada \\ G.B. Stenhouse Foothills Research Institute, Canada
}

M. Symbaluk Teck Resources Limited, Canada

M.S. Boyce Department of Biological Sciences, University of Alberta, Canada

\begin{abstract}
Gauging the success of industrial reclamation requires targets to be set for restoring ecosystem structure and function. An indication of reclamation success is if wildlife recolonize, forage, rest, reproduce and survive on reclaimed areas. The grizzly bear is a threatened species that exists at low densities in Alberta, Canada and facilitates a variety of ecosystem processes. To make suggestions for mitigating the effects of open pit mining on this species, we collected and analysed biological data for grizzly bears on and around Cheviot, Luscar and Gregg River coal mines in west-central Alberta. During 2008-2010, we captured and attached GPS radiocollars on 12 adult bears on and around mines which allowed us to intensively track their movements.
\end{abstract}

We visited bear used GPS locations in the field to assess bear activity and microhabitat characteristics. Bears selected reclaimed mines and areas near mines extensively in late spring and early summer to forage on forbs sown as part of mine reclamation and to depredate ungulate calves and lambs. In the fall, bears moved primarily in areas outside mines to forage on berries in preparation for winter denning. Bears often bedded in dense tree cover which underlines the importance of maintaining original vegetation patches in planning mine operations. The animals sometimes crossed the major active mine haul road and moved on and near trails designated for human access on mine leases.

High mortality risk associated with expansion of human access into previously remote areas is a major threat to long-term persistence of the grizzly bear population. Defensive driving and potentially enforcement of speed restrictions on mine haul roads in areas with high frequency of bear crossings, provisioning for ecological movement corridors and proper waste management practices will help prevent human-bear conflict during the active mining phase. Following closure of mines, access management along designated trails will reduce the risk of conflicts. Imposing access restrictions, along with preserving undisturbed habitat patches and restoring the original vegetation cover will enable coexistence of people and bears on a shared landscape.

\section{Introduction}

Open-pit mining is a large-scale industrial activity that modifies habitat by reshaping landscapes and removing the original vegetation. Following closure of active mining operations the land is reclaimed with the reclamation objective being the progressive re-establishment of self-sustaining landscapes that incorporate wildlife habitat. Wildlife recolonization of reclaimed areas is on its own not an appropriate indicator for the success of reclamation. Animals may perceive reclaimed areas to be unsuitable and simply move through without engaging in the full suite of natural behaviours. A more desirable measure of reclamation success is whether animals exhibit the full range of natural behaviours on reclaimed areas.

Current knowledge on the effects of active mining operations and reclamation on large mammals comes primarily from research on ungulates. Ungulate species may respond differently to surface mining activity and mine reclamation that carnivores. Caribou (Rangifer tarandus) can displace spatially up to $4 \mathrm{~km}$ away from active mine leases (Weir et al., 2007). Bighorn sheep (Ovis canadensis) appear to be less influenced by mining activity (Jansen et al., 2009) and readily recolonized and increased in abundance on Luscar and Gregg River reclaimed coal mines in west-central Alberta, from 35 pre-mining to currently around 1,000 
individuals (Bighorn Wildlife Technologies, 2010). Elk (Cervus elaphus) numbers experienced a fast upward trend on the same reclaimed mines and currently number around 400 individuals (Bighorn Wildlife Technologies, 2010). The expansion was likely due to increase in availability of forage for ungulates by sowing forbs, grasses and sedges as part of reclamation.

The effects of open pit mining on carnivores are largely unknown. Top carnivores are important in the structure and functioning of ecosystems and although their overall biomass is low compared to herbivores and plants, carnivores are crucial to maintaining biodiversity (Ale and Whelan, 2008). The grizzly bear (Ursus arctos horribilis) is a keystone species iconic for the wilderness of the Rocky Mountains. Through deposition of scat, grizzly bears facilitate the dispersal and germination of plant seeds they consume (Willson and Gende, 2004). When foraging by digging for plant roots, grizzly bears affect plant distributions and mineral nitrogen availability (Tardiff and Stanford, 1998). Research in Alaska (Adams et al., 1995) and Yellowstone National Park (Mattson, 1997) has showed that grizzly bears can have important effects on ungulate populations through predation.

Of all North American large carnivores, grizzly bears have low resiliency to human-born threats because of requirement for large patches of undisturbed habitat, low reproductive rates, and potential to get into conflict with humans (Weaver et al., 1996). Consequently, the grizzly bear has experienced dramatic decline throughout its range in North America (Servheen et al., 1999). Habitat fragmentation and persecution by humans are the major causes of the documented decline, which is well illustrated by the current status designation of the grizzly bear in Alberta, Canada (Threatened status conferred in 2010). The present range of grizzly bears in Alberta has been pushed westward by human encroachment and the majority of known grizzly bear mortalities are human-caused and occur within $500 \mathrm{~m}$ of a road or access trail (Benn and Herrero, 2002).

The province-wide grizzly bear population estimate, based primarily on DNA sampling from bear hair collected at baited sites (Grizzly Bear Inventory Team, 2007), showed that less than 800 grizzly bears occur outside National Parks, with the overall Alberta grizzly bear population being estimated at less than 1,000 individuals. A Grizzly Bear Recovery Plan for the province was put forward in 2008 (Alberta Grizzly Bear Recovery Team, 2008). The Plan stresses that bear numbers are low because of human-caused mortalities associated with expansion of industry, recreation and agricultural practices and has been supported by a recent review of grizzly bear status in the province (Government of Alberta, 2010). The Plan underlines the need for studies that fill knowledge gaps on the effects of industrial developments on grizzly bear habitat, ecology and behaviour.

With resource extraction industries such as mining projected to expand in Alberta, an assessment is rapidly needed for the effects of mining on the grizzly bear. The purpose of this study was to assess grizzly bear response to open-pit mining and reclamation, by documenting bear foraging, movement, habitat ecology and behaviour, on and around coal mine leases. As a case study, investigations focused on mineral surface leases (MSLs) located near the Hamlet of Cadomin, at the interface between the Eastern Slopes of the Rocky Mountains and Foothills. Based on our research findings we also wanted to formulate suggestions for mine reclamation and active mining operations that minimized any negative effects of mining on grizzly bears.

\section{Methods}

The field component of the study was carried out during 2008-2010 in west-central Alberta, at the interface between the Eastern Slopes of the Rocky Mountains and Foothills. A 10,000 $\mathrm{km}^{2}$ study area was delineated south of the town of Hinton, with the area being bordered to the north by Highway 16. The predominant natural land cover in the region is coniferous forest dominated by white spruce (Picea glauca) and lodgepole pine (Pinus contorta) with deciduous forest composed of balsam polar (Populus balsamifera) and trembling aspen (Populus tremuloides) also present at lower elevations and on sunny south and east facing slopes. Elevation and ruggedness are greater in the western section of the study area which is mountainous with the eastern section being characterized by rolling hills.

Human activities in the study area include: open-pit coal mining, forest harvesting, oil and gas development and recreational activities (All Terrain Vehicles, hunting, hiking and camping) with the mountainous areas generally having less human activity. The area encompasses three open-pit coal mine MSLs located near the 
Hamlet of Cadomin (population 60). Within a mining area, trees and other surface vegetation are removed and excavations are being done to extract coal. During this study, Luscar MSL had a total area of 4,381 ha, with 2,382 ha being disturbed, of which 1,195 ha were unreclaimed and 787 ha reclaimed. The 1,195 ha unreclaimed included 400 ha still supporting active mining. Gregg River had a total area of 3,700 ha of undisturbed and fully reclaimed lands. Cheviot MSL had an area of 1,600 ha of which 650 ha were active and 950 ha undisturbed. Other land designations in the study area include public (Crown) lands and protected areas (Whitehorse Wildland Park and part of the eastern sector of Jasper National Park) (Fig. 1).
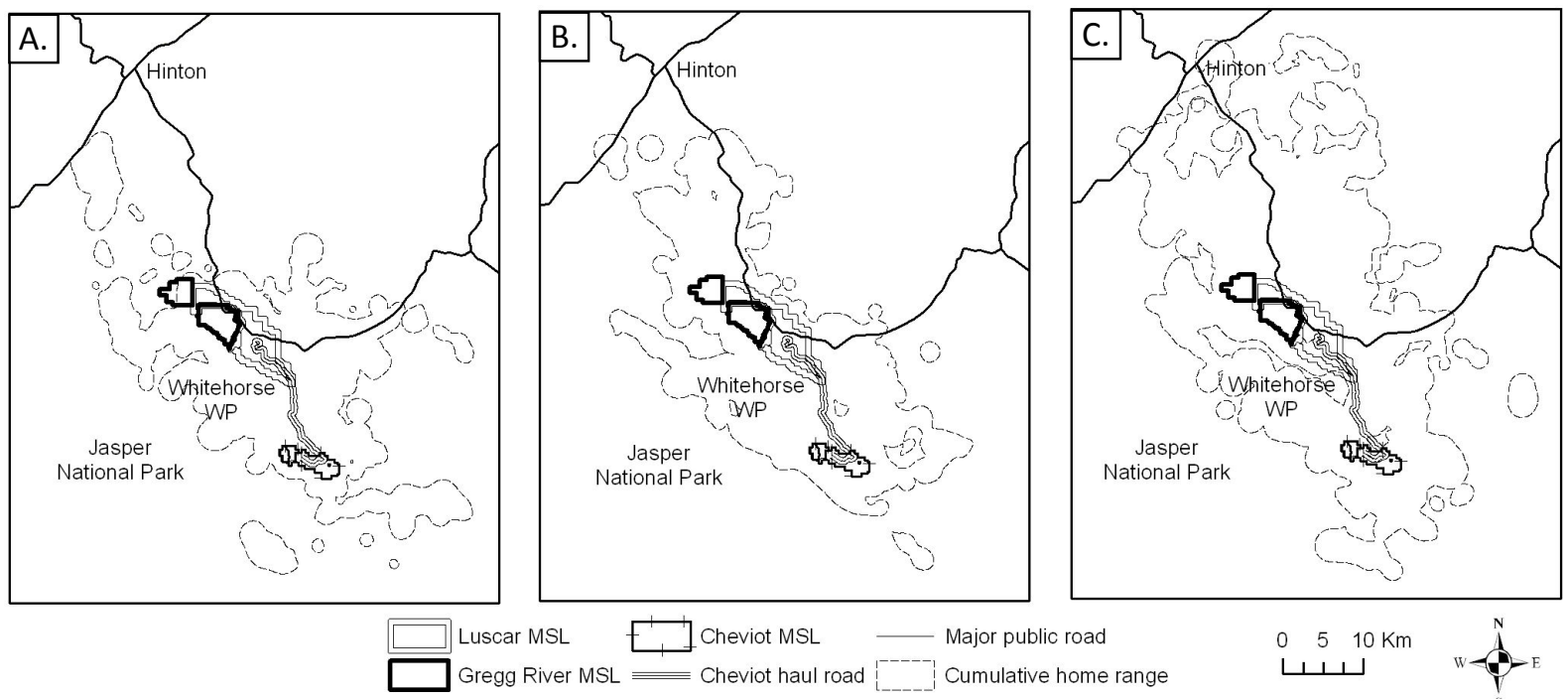

Figure 1 The study area in west-central Alberta, Canada included open-pit mine leases, protected areas and public lands. Cumulative grizzly bear home ranges for three seasons were generated by merging $95 \%$ fixed kernels of individual radiocollared bears across the 2008-2010 monitoring period: A. Hypophagia (spring), B. Early hyperphagia (summer) and C. Late hyperphagia (fall).

Each year during spring and fall we captured and set GPS radiocollars (Telus UHF, Followit, Sweden) on adult grizzly bears on and near the MSLs. All bears were captured and handled according to Animal Care and Use protocols approved by the University of Saskatchewan and University of Alberta. We used baited culvert traps, leg-hold snares and remote darting from helicopter to capture bears and chemically immobilize them with a combination of Xylazine-Telazol (XZT) reversed by Atipamezole. Each radiocollar had a unique radio beacon frequency allowing us to track individual bears in the field. We programmed the radiocollars to acquire a GPS location every hour, 24-h/day, during March 15-December 1 when the bears were mostly outside their winter dens. Based on field trials the GPS radiocollar accuracy was $\pm 10 \mathrm{~m}$.

Every month during the non denning period we located bears from the ground, fixed-wing aircraft or helicopter based on the collar VHF radio beacon. To acquire GPS locations from collared bears, we approached each bear to within a safe distance that allowed remote data downloads from the collars. We then downloaded the GPS collar data to a laptop computer and plotted the locations in a GIS system to visualize where the animal had moved during the past month. We selected a sample of locations for each bear during each month (largest four location clusters and random other clusters) and uploaded them to hand-held GPS units so that we could visit these sites in the field. During May-November, field crews hiked to visit the selected GPS locations where they recorded general habitat characteristics and bear activity. For safety and logistical reasons, visits occurred 2-4 weeks after the bear had left the general area.

We incorporated a temporal component in our data analysis to account for seasonal variation in grizzly bear food availability in our study area. Following Nielsen et al. (2004a), we divided our data into three seasons: "hypophagia" (spring; den emergence to June 14), "early hyperphagia" (summer; June 15 to August 7) and "late hyperphagia" (fall; August 8 to den entrance). Grizzly bears in west-central Alberta dig for sweet vetch roots (Hedysarum spp.) and feed on ungulate carcasses in hypophagia, graze forbs and grasses in early hyperphagia and feed on berries and ungulates in late hyperphagia (Munro et al., 2006). 


\subsection{Home range overlap with mine leases}

Using $95 \%$ of the GPS locations acquired remotely from radiocollared bears (to account for $5 \%$ potential GPS erroneous locations), we calculated fixed kernel bear home ranges for each of the three seasons. For each bear in each season, we extracted home range areas that overlapped MSLs and calculated the proportion of home range overlap with leases by dividing the home range area on a lease by the total home range area of the respective bear in a given season. Similarly, we calculated proportion of the home range area present outside leases and compared proportion of the home range that overlapped mines with the proportion that occurred outside mines.

\subsection{Bear activity on vs. outside mines}

We used data from visits of bear GPS location clusters sampled in the field to plot frequency of bear activity standardized to percentage. During the first month of 2008 field visits we investigated locations picked at random from the GPS radiocollar data. Subsequently, because we were primarily interested in bear activity other than simple travel through an area, we focused visits on GPS location clusters where bears had spent at least 3 hours within a $30 \mathrm{~m}$ radius. Overall we recorded eight types of bear activity with some sites having more than one type of activity. Bear sign of activity that we recorded was either foraging (feeding on an ungulate carcass, ants or rodents, digging for plant roots, grazing on upper plant parts, or feeding on berries), resting (bedding) or possible territorial marking (claw marking on trees). For a small set of sites visited in the field $(<4 \%)$ we were not able to identify bear activity despite intensive search efforts of the area.

\subsection{Bedding and ungulate kill site selection}

Because bedding and feeding on ungulate carcasses formed $80 \%$ of findings at GPS locations clusters visited in the field indicating that bears spend a lot of time engaged in these activities, we assessed the type of habitat these activities occurred in.

Because of small sample sizes for the Cheviot active MSL (13 sites), we performed the analyses for reclaimed mines only and classified habitat into three categories: forest (land cover undisturbed by mining i.e. original tree patches on MSLs), grassland (vegetated areas previously disturbed by surface mining and subsequently reclaimed to grasses and forbs) and barren land (unvegetated patches such as rocky formations and steep walls from old mine pits). We calculated Manly's habitat selection ratios for bear bedding and ungulate carcasses according to an use-availability design (Johnson et al., 2006). We sampled habitat availability by generating 238 (Gregg River MSL) and 400 (Luscar MSL) random GPS locations respectively with differences in number of random locations proportional to the difference in surface extents between Luscar and Gregg River MSLs. We focused on categorical habitat classes for this analysis because we were interested in assessing the extent to which these activities occur in undisturbed $v s$. disturbed habitat on mines. Future analyses will incorporate other potentially important variables such as distance to habitat edges and ungulate availability on the landscape.

\subsection{Cheviot haul road crossings}

The $23.84 \mathrm{~km}$ long Cheviot haul road follows for the most part the McLeod River Valley and receives traffic 24-h/day. The mean frequency of heavy haul truck traffic is one every 10 minutes, whereas light and support vehicles are intermittent. In order to investigate the possible impacts of active mine haul roads on grizzly bear movements and habitat use, we divided the Cheviot mine haul road into $500 \mathrm{~m}$ segments to calculate the frequency of road crossings by radiocollared bears according to season. We connected 1-hr consecutive GPS radiocollar locations with straight lines and considered these as movement "steps" that the bears took on the landscape. We then intersected all steps that crossed the haul road with the $500 \mathrm{~m}$ road segments and mapped the frequency of road crossings. We recognize that this technique will represent a minimum number of crossings and is thus likely an underestimation of all crossings. 


\subsection{Bear use of areas near mine trails}

Public access on MSLs is permitted only along designated access trails that are either non-motorized or motorized. To investigate bear use of areas near designated trails that cross reclaimed mines, we created 500 $\mathrm{m}$ buffers around each side of the trails. We considered motorized trails (ATV and dirt bike access permitted) separately from non-motorized trails (hiking, horseback riding and biking only allowed). We then counted the number of bear GPS locations within each buffer by season to identify trail type and season for which grizzly bear use of access trails and adjacent habitats is high.

We performed geospatial analyses in ArcGIS 9.2., basic statistical calculations in MS Excel and used STATA to graph our results. Habitat selection ratios were computed using software R.

\section{Data}

In 2008-2010 we set radiocollars on 12 adult bears ( 6 males; 6 females) in the study area which was assumed a random sample of the grizzly bear population of the area. One male slipped the collar off within a week of capture and a second male dropped the collar within a month. The 10 remaining bears provided data for variable amounts of time, from one season to three years, depending on when the bear was captured, premature collar slip-off or collar malfunctioning (Table 1). All 10 bears crossed at least one of the three MSLs under study during the monitoring period.

Table 1 Adult grizzly bears monitored in 2008-2010 on and around coal mineral surface leases (MSLs) in west-central Alberta, Canada.

\begin{tabular}{llllll}
\hline $\begin{array}{l}\text { Bear } \\
\text { ID }\end{array}$ & Sex & $\begin{array}{l}\text { Years } \\
\text { monitored }\end{array}$ & $\begin{array}{l}\text { GPS locations } \\
\text { on Luscar MSL }\end{array}$ & $\begin{array}{l}\text { GPS locations on } \\
\text { Gregg River MSL }\end{array}$ & $\begin{array}{l}\text { GPS locations on } \\
\text { Cheviot MSL }\end{array}$ \\
\hline G023 & Female & 2 & 1734 & 440 & 0 \\
G037 & Female & 1 & 245 & 1280 & 0 \\
G053 & Male & $1<$ & 43 & 5 & 0 \\
G110 & Male & 2 & 0 & 0 & 71 \\
G111 & Female & 3 & 299 & 341 & 204 \\
G112 & Male & 1 & 315 & 219 & 4 \\
G113 & Female & 2 & 1245 & 19 & 0 \\
G115 & Male & 2 & 556 & 655 & 0 \\
G117 & Female & 2 & 0 & 0 & 228 \\
G118 & Female & 1 & 273 & 229 & 0 \\
\hline
\end{tabular}

During May-November 2008-2010 we visited 573 GPS locations used by bears on Luscar MSL $\left(n_{L}=113\right)$, Gregg River MSL $\left(n_{G R}=57\right)$, Cheviot MSL $\left(n_{C}=13\right)$ and outside mines $\left(n_{O M}=390\right)$.

\section{Results}

\subsection{Home range overlap with mine leases}

Areas outside mine leases included higher proportions of bear home ranges than areas on mines (median $>0.75$ ). Of all mine leases considered, proportion home range overlap was highest for Luscar MSL, a pattern which was consistent regardless of season. Reclaimed mines (Luscar and Gregg River MSLs) made up the highest proportion of bear home ranges during early hyperphagia, when correspondingly areas outside mines had the lowest proportion of bear home ranges of all seasons. As expected, Cheviot MSL where active mining occurred had the lowest proportion of home range overlap. Individual variation between bears was 
apparent, with two bears (depicted as medium grey outliers in Fig.2 below) having a large proportion of their home ranges on Gregg River MSL during hypophagia and early hyperphagia (median $>0.4$ ). In late hyperphagia, for most bears only a small proportion of home ranges overlapped reclaimed and active MSLs (median <0.05). Grizzly bears have large home range requirements because they need to cover vast areas in search for both food and mates. The MSLs considered in our study represented only a small proportion of where most bears moved during the monitoring period, but bears did use reclaimed mines for foraging, resting and tree marking (discussed below).

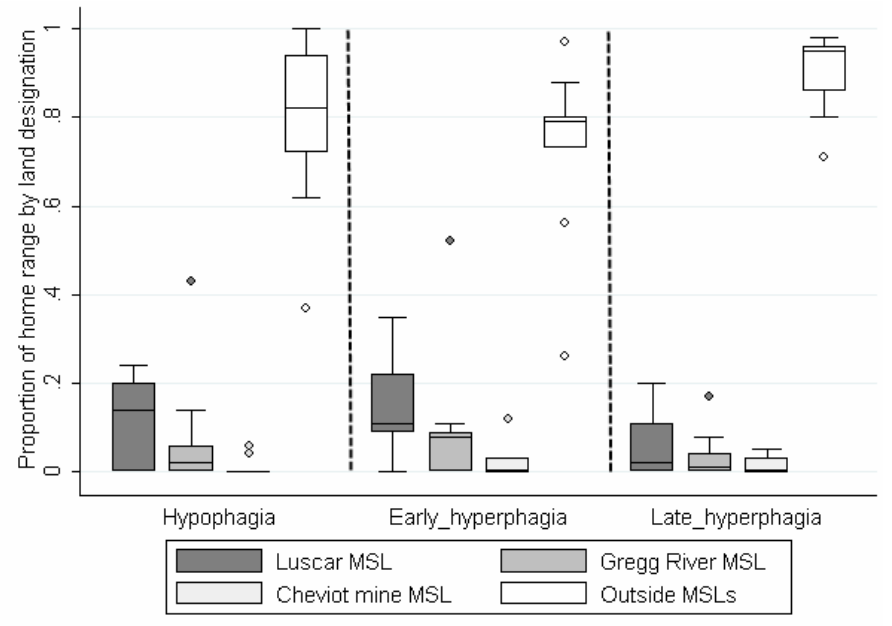

Figure 2 Proportion of grizzly bear home ranges ( $95 \%$ fixed kernels) overlapping with mine leases and areas outside mines by season. Data are for 10 grizzly bears monitored in 2008-2010 on and around reclaimed (Luscar MSL; Gregg River MSL) and active (Cheviot MSL) open-pit coal mines in westcentral Alberta.

\subsection{Bear activity on vs. outside mines}

A variety of bear activity types were recorded at sites visited in the field (Fig. 3), denoting the opportunistic feeding habits of bears and the fact that some individual bears were more carnivorous whereas others primarily herbivorous. Sample sizes (number of sites with a specific activity) differ for each activity, with the primary activity recorded being bedding (resting) followed by feeding on ungulate carcasses and digging for plant roots. Rodent digging, feeding on ants and tree marking (tree rubbing and claw marking) were only recorded at 12-15 sites each.

Most bear activity we recorded was outside mine leases ( $>60 \%$ with the exception of herbaceous feeding), reflecting our sampling regime biased towards visiting GPS location clusters, more of which formed outside mines compared to on mine sites. Reclaimed mines had more bear activity than the active Cheviot MSL and no activity on the Cheviot pits, a pattern in accordance to low bear home range overlap with Cheviot MSL as compared to reclaimed mines. Also in accordance to higher proportions of bear home range overlap compared with the other mine leases, Luscar MSL had the highest percentage of bear activity of all mines. Feeding on ungulates and root digging in particular appear to be occurring more on Luscar than on the other mine leases. The one exception to this pattern was herbaceous feeding which appears to occur in equal proportions on Luscar and Gregg River MSLs and outside mines, when the data are pooled across seasons. We suspect that herbaceous feeding actually occurs preferentially on reclaimed mines, but unfortunately small sample sizes for this activity preclude seasonal analyses. No instance of berry feeding was recorded on mine leases, which is likely a reflection of low availability of berries on MSLs (unpublished data). The lack of records of berry feeding on mines is consistent with the pattern of small proportion of home ranges overlapping mines in late hyperphagia, when berry feeding typically occurs. 


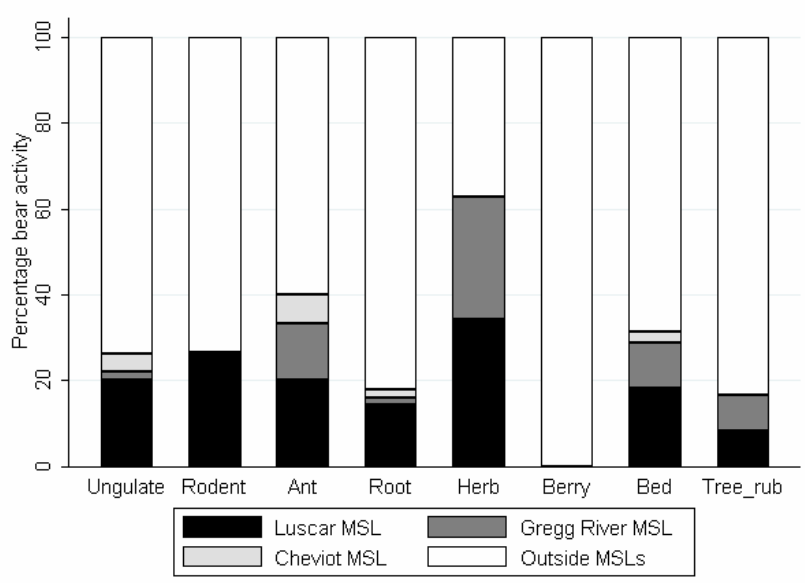

Figure 3 Percentage bear activity on mine leases and areas outside mines by season, based on 573 bear used locations visited by field teams. Data are pooled across seasons for 10 grizzly bears monitored in 2008-2010 on and around reclaimed (Luscar MSL; Gregg River MSL) and active (Cheviot MSL) open-pit coal mines in west-central Alberta.

\subsection{Bedding and ungulate kill site selection}

On Luscar MSL, bears selected forested (undisturbed) habitat and avoided grassland and barren land for bedding (Luscar MSL: standardized selection ratios $\beta_{\text {forest }}=0.841, \beta_{\text {grassland }}=0.071, \beta_{\text {barren }}=0.087$ ). The same pattern was observed for Gregg River MSL, except that barren land actually was selected by bears for bedding (Gregg River MSL: standardized selection ratios $\beta_{\text {forest }}=0.494, \beta_{\text {grassland }}=0.110, \beta_{\text {barren }}=0.396$ ). Barren land on Gregg River MSL is found primarily on rock walls of old pits often reclaimed to freshwater lakes. Statistically, apparent bed-site selection of barren land is unreliable and likely a product of small sample sizes resulting in high standard errors. Biologically, given that the highest home range overlap for this MSL occurs in early hyperphagia (summer), bears may bed on barren land so that they can access water quickly.

Ungulate consumption sites on reclaimed mines were selected for primarily in forested areas, with grassland and barren land areas being negatively selected (Luscar MSL: standardized selection ratios $\beta_{\text {forest }}=0.906$, $\beta_{\text {grassland }}=0.037, \beta_{\text {barren }}=0.057$; Gregg River MSL: standardized selection ratios $\beta_{\text {forest }}=1, \beta_{\text {grassland }}=0, \beta_{\text {barren }}=0$ ). Forests may provide more suitable cover for stalking and predating on ungulates compared to open habitats where predators are easier to detect. Hunting strategies that make use of forest cover and potentially habitat edges (the influence of which will be tested in future analyses) may be favored by predators other than bears as well. After a kill is made by cougars (Puma concolor) (Murphy et al., 1998) or wolves (Canis lupus) (Wilmers et al., 2003), grizzly bears may displace these predators from ungulate kills. Indeed, scavenging is an important part of bear diet in our study area (unpublished data).

\subsection{Cheviot haul road crossings}

Maintaining habitat connectivity is essential for long-term persistence of wildlife species with wide-ranging requirements such as large carnivores (Chetkiewicz et al., 2006). Roads and high traffic volumes can be major barriers to animal movement and can impede genetic flow between populations thereby affecting population fitness. Intensive monitoring of bear movement using GPS radiocollar technologies revealed that bears do cross the active haul road and allowed us to identify sections of the road with high frequency of crossings. Most road crossings occurred during early hyperphagia and especially in the northern sections of the road, in areas where the road crosses Luscar MSL (Fig. 4). On this reclaimed mine public access is restricted to designated trails only and bears graze on vegetation and kill ungulates on the lease. In late hyperphagia, another area where crossings were concentrated was $500 \mathrm{~m}$ north of Prospect Creek's junction with the McLeod River. Few crossings occurred in the southern sections of the road possibly because the Cheviot haul road and active pits couple with motorized public access along a county road that follows the McLeod River and crosses the Cheviot MSL. However, one bear crossed the haul road on Cheviot MSL on 
several occasions, moved near the mine offices and made two ungulate kills in an undisturbed patch of forest at the centre of the active mining operations.
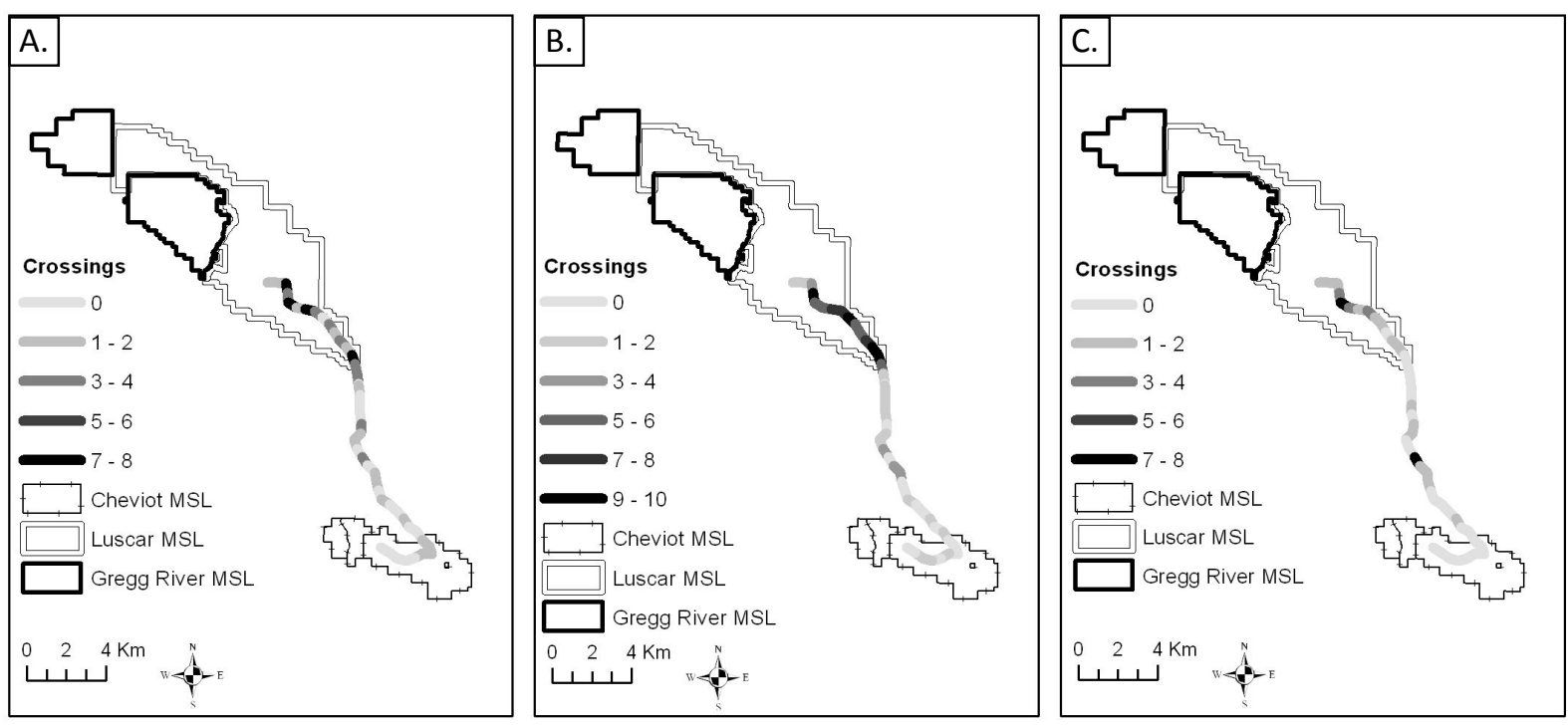

Figure 4 Frequency of Cheviot coal mine haul road crossings by radiocollared grizzly bears in 20082010, by season. High crossing frequency is given in darker shades of grey. The haul road was active 24-h/day during the period of grizzly bear monitoring. A. Hypophagia (spring), B. Early hyperphagia (summer) and C. Late hyperphagia (fall).

\subsection{Bear use of areas near mine trails}

In Alberta, most human caused grizzly bear mortalities occur within $500 \mathrm{~m}$ of a road or human use trail. Opening of roads and trails facilitates human access into previously remote areas and increases the chance of human-bear interactions. Of all trail types and seasons, non-motorized trails in early hyperphagia had the highest occurrence of bear locations (Fig. 5). Early hyperphagia is the time of the year when bears graze on forbs and kill ungulates on reclaimed MSLs, whereas in late hyperphagia bears move outside MSLs to feed on berries. For motorized and non-motorized trails, we found that late hyperphagia is the season with the lowest occurrence of grizzly bear locations along trails. Late hyperphagia also corresponds to the ungulate hunting season, when trails receive high levels of motorized traffic (unpublished data). Future analyses based on precise quantification of human use of access trails will allow an assessment on whether the seasonal difference in food availability or the difference in intensity of human use of trails is the key driving factor for grizzly bear occurrence along trails. 


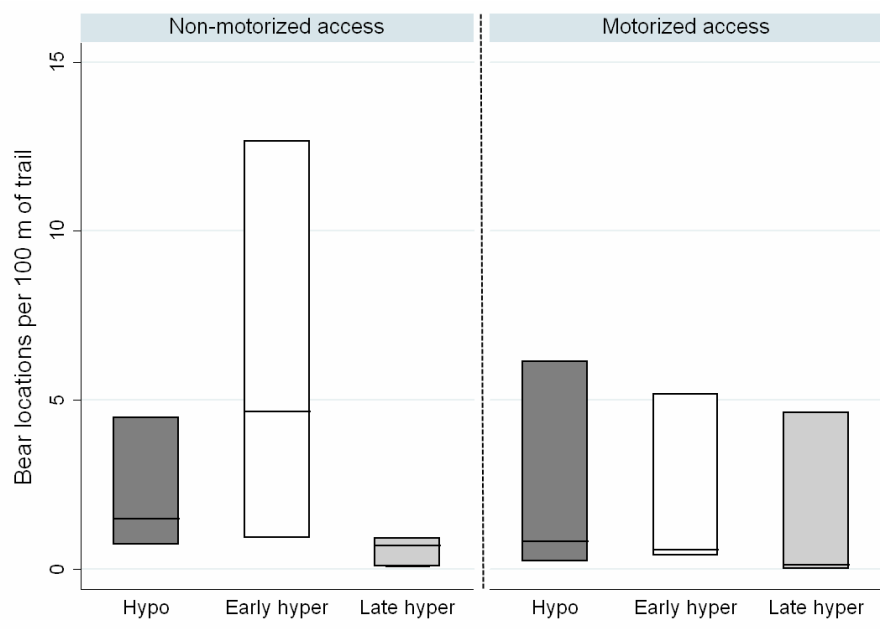

Figure 5 Occurrence of grizzly bears in a $500 \mathrm{~m}$ buffer along designated access trails on Luscar and Gregg River reclaimed MSLs. Each box plot represents one season (hypophagia, early hyperphagia and late hyperphagia) and the data are split by non-motorized $\left(n_{1}=3\right)$ and motorized $\left(n_{2}=3\right)$ access trails. Occurrence data are from GPS radiocollared bears monitored during 2008-2010 in west-central Alberta.

\section{Conclusions}

Grizzly bears have recolonized, forage and rest on reclaimed open-pit coal mines in west-central Alberta. The proportion of bear home range overlap with reclaimed MSLs was highest in spring/early summer (hypophagia and early hyperphagia). Luscar MSL had the highest proportion of bear home range overlap followed by Gregg River MSL, whereas Cheviot MSL had the lowest, indicating that bears may select reclaimed mines while avoiding active mining operations. On reclaimed MSLs, bears graze on vegetation and kill ungulates, with kills found primarily in forested areas and few carcasses out in vast open areas which dominate reclaimed mines. Reclaimed mines provide not only forage but also resting habitat opportunities for bears with bed sites occurring primarily at the shelter of original tree patches undisturbed during the active mining phase. This finding along with the spatial distribution of ungulate carcasses consumed by bears suggest that if the management objective is to enable bear use of reclaimed mines then large original forest patches should be maintained in mine planning.

High risk of human-caused mortalities associated with expansion of access into previously remote areas is a major threat to the long-term viability of grizzly bears (Nielsen et al., 2004b). Conflicts may arise along roads used for mining activity or along recreational trails used by the public. Although we haven't recorded any bear mortality resulting from collision with haul road traffic, bears cross the active Cheviot mine haul road primarily at its northern sections suggesting that the potential for collision exists. We intuitively suspect that enforcing speed limits along the haul road particularly in spring and summer when crossings are the most frequent will decrease the likelihood of road mortality. Any users of mine haul roads should be informed about the risk of wildlife crossing the roads and road warning signs should signal areas where crossings are most likely to occur. Proper waste management practices will help prevent attracting bears to mine buildings and storage compounds thus decreasing the chance of conflict during active mining.

Given that bears use reclaimed mines in spring and early summer, conflict prevention strategies should involve human access management by allowing access along designated trails only. During early hyperphagia, when bear home ranges have the largest overlap with mine leases, human access can be temporarily prohibited by closure of trails with high risk of conflict. Bear warning signs could be installed at trail heads to inform the public about the risk of bear encounters and should include recommendations on carrying a non-lethal deterrent such as bear spray. These signs should be left along trails for all bear active seasons, because although lower, the risk of encounters still exists for fall (late hyperphagia). Lack of access 
regulations would expose the public to an increase in chances of bear encounters resulting in an increase in the probability of conflict.

Educating active haul road users about the potential for collisions with wildlife, regulating access along recreational trails, preserving undisturbed forest patches and ideally restoring the original (forested) vegetation cover will help mitigate the effects of mining development on grizzly bears.

\section{Acknowledgements}

We thank all partners that made this project possible: Alberta Conservation Association, Alberta's Conservation Collaboration, Alberta Ingenuity Fund, Alberta Sport, Recreation, Parks \& Wildlife Foundation, American Society of Mammalogists, Canadian Wildlife Federation, Foundation for North American Wild Sheep - Alberta Chapter, International Association for Bear Research and Management, Mountain Equipment Co-op, Safari Club International - Northern Alberta Chapter, TD Friends of the Environment Foundation, Teck Resources Limited, and the University of Alberta. Valuable in-kind consultation and support were provided by: Alberta Parks, Alberta Sustainable Resource Development, Athabasca Bioregional Society, Bighorn Wildlife Technologies, Foothills Research Institute, Hab-Tech Environmental and Parks Canada. Assistance from Bernie Goski, Terrence Larsen, John Saunders and Steve Wotton made bear captures possible. Karen Graham and Julie Duval provided GIS support. Several dedicated field technicians volunteered their time to visit locations used by bears.

\section{References}

Adams, L.G., Singer, F.J. and Dale B.W. (1995) Caribou calf mortality in Denali National Park, Alaska. Journal of Wildlife Management, Vol. 59, pp. 584-594.

Alberta Grizzly Bear Recovery Team (2008) Alberta Grizzly Bear Recovery Plan 2008-2013, viewed 20 March 2011, http://www.srd.alberta.ca/ManagingPrograms/FishWildlifeManagement/BearManagement/documents/Grizzly Bear-RecoveryPlan2008-13-revJuly23-2008.pdf

Ale, S.B. and Whelan C.J. (2008) Reappraisal of the role of big, fierce predators! Biodiversity Conservation, Vol. 17, pp. 685-690.

Benn, B. and Herrero, S. (2002) Grizzly bear mortality and human access in Banff and Yoho National Parks, 19711998. Ursus, Vol. 13, 213-221.

Bighorn Wildlife Technologies (2010) Cheviot and Luscar Mine Wildlife Inventory 2009, Teck Coal Limited, Cardinal River Operations, created for Teck Coal Limited, Cardinal River Operations Hinton, AB, by Bighorn Wildlife Technologies Ltd., Hinton, AB (confidential, cited with permission), 35 p.

Chetkiewicz, C-L.B., St. Clair, C.C., and Boyce, M.S. (2006) Corridors for conservation: Integrating pattern and process. 2006. Annual Review of Ecology, Evolution and Systematics, Vol. 37, 317-342.

Government of Alberta (2010) Status of the grizzly bear (Ursus arctos) in Alberta, viewed 20 March 2011, http://srd.alberta.ca/biodiversitystewardship/speciesatrisk/DetailedStatus/documents/Status-GrizzlyBearinAlberta-Feb2010.pdf

Grizzly Bear Inventory Team (2007) Alberta DNA population estimate reports 2004-2007, viewed 20 March 2011, http://www.srd.alberta.ca/ManagingPrograms/FishWildlifeManagement/BearManagement/GrizzlyBears/Grizzl yBears.aspx

Jansen, B.D., Krausman, P.R, Bristow, K.D., Heffelfinger, J.R., and deVos, J.C. Jr. (2009) Surface mining and ecology of desert bighorn sheep. Southwestern Naturalist, Vol. 54, pp. 430-438.

Johnson, C.J., Nielsen, S.E., Merrill, E.H., McDonald, T.L. and Boyce, M.S. (2006) Resource selection functions based on use-availability data: theoretical motivation and evaluation methods. Journal of Wildlife Management, Vol. 70, pp. 347-357.

Mattson, D.J. (1997) Use of ungulates by Yellowstone grizzly bears Ursus arctos. Biological Conservation, Vol. 81, pp. 161-177.

Munro, R.H.M., Nielsen, S.E., Price, M.H., Stenhouse, G.B. and Boyce, M.S. (2006) Seasonal and diel patterns of grizzly bear diet and activity in west-central alberta. Journal of Mammalogy, Vol. 87, pp. 1112-1121. 
Murphy, K.M., Felzien, G.S., Hornocker, M.G. and Ruth, T.K. (1998) Encounter competition between bears and cougars: some ecological implications. Ursus, Vol. 10, pp. 55-60.

Nielsen, S.E., Boyce, M.S. and Stenhouse, G.B. (2004a). Grizzly bears and forestry I. selection of clearcuts by grizzly bears in west-central Alberta, Canada. Forest Ecology and Management, Vol. 199, pp. 51-65.

Nielsen, S.E., Herrero, S., Boyce, M.S., Mace, R.D., Benn, B., Gibeau, M.L. and Jevons, S. (2004b) Modelling the spatial distribution of human-caused grizzly bear mortalities in the Central Rockies ecosystem of Canada. Biological Conservation, Vol. 120, pp. 101-113.

Tardiff, S.E. and Stanford, J.A. (1998) Grizzly bear digging: effects on subalpine meadow plants in relation to mineral nitrogen availability. Ecology, Vol. 79, pp. 2219-2228.

Weaver, J.L., Paquet, P.C. and Ruggiero, L.F. (1996) Resilience and conservation of large carnivores in the Rocky Mountains. Conservation Biology, Vol. 10, pp. 964-976.

Weir, J.N., Mahoney, S.P., McLaren, B. and Ferguson, S.H. (2007) Effects of mine development on woodland caribou Rangifer tarandus distribution. Wildlife Biology, Vol. 13, pp. 66-74.

Willson, M.F. and Gende, S.M. (2004) Seed dispersal by brown bears, Ursus arctos, in Southeastern Alaska. Canadian Field Naturalist, Vol. 118, pp. 499-503.

Wilmers, C.C., Crabtree, R.L., Smith, D.W., Murphy, K.M. and Getz, W.M. (2003) Trophic facilitation by introduced top predators: grey wolf subsidies to scavengers in Yellowstone National Park. Journal of Animal Ecology, Vol. 72, pp. 909-916.

Servheen, C., Herrero, S. and B. Peyton (eds.) (1999) Status survey of the bears of the world and global conservation action plan. IUCN, Gland, Switzerland. 